\title{
透磁層の形成とその充填機構に関する研究 \\ STUDY ON THE FORMATION OF OPENWORK GRAVEL LAYERS AND ITS FILLING-UP MECHANISM WITH MATRICES
}

\author{
福島雅紀 1 ・末次忠司 2 ・瀬崎智之 ${ }^{3}$ \\ Masaki Fukushima, Tadashi SUETSUGI and Tomoyuki SEZAKI \\ 1正会員 工博 国土技術政策総合研究所河川研究部河川研究室 主任研究官 (テ 305-0804 つくば市旭 1) \\ 2 正会員 工博 国土技術政策総合研究所河川研究部河川研究室 室長 (同上) \\ 3 正会員 工修 国土地理院企画部企画調整課 課長補佐 (テ305-0811 つくば市北郷1番)
}

\begin{abstract}
Gravel layers of gravel-bed river are commonly filled with matrices of sand and silt. In some fluvial conditions, there are "openwork gravel layers", that is, gravel layers without matrices.

In this study, the formation of openwork gravel layers was observed in a field, and a filling-up process was also observed. The filling-up rates were measured under several hydraulic conditions in a flume, where the process was demonstrated and the rate was measured by putting iron powder into upstream end of the observed point at fixed intervals during the filling up process of openwork gravel layer. Summarizing these results, the rate of its filling-up process was predicted by a simple formula.
\end{abstract}

Key Words : Openwork gravel layer, Suspended sediment, filling up, vegetation

\section{1. はじめに}

近年，河道内樹林化の問題と関連して，礫床河川の特 徵としての河原の存在が議論されることが多く, 河原を 持続的に維持するためには河床に対する適度な頻度の擋 乱(洪水等)の発生が不可欠であることが指摘される. 服 部ら ${ }^{1)}$ は，流水の作用を受ける河道内に立地する植物群 落の変化を捉えて，「河原の形成乡草本の繁茂乡樹林 化」を洪水の作用と関連付けて一つのシステムとしての 捉えているが，今後は土砂の堆積を予測することが重要 であると述べている，それに関連して，草本群落内での

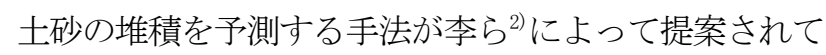
いるが，洪水後に形成される河床の状態を予測する手法 については未解明な点が多い.この撹乱によって生じる 河床表層の状態は，植物の繁茂速度やそこに繁茂する植 物を規定する上で重要な要素となる．例えば，洪水後に 透磎層が形成された場合には，そこには長期間にわたっ て裸地が形成される. また，マトリクスやマトリクス， が形成された場合には，草本群落が進入しやすく，その 後の土砂の堆積, そして植物群絡の拡大, さらには撹乱 の頻度にもよるが樹林へと遷移することが予測される.

河床は主に碟，砂およびシルトによって構成される. 図-1は河床表層の状態をそれらの存在状態から分類した
ものであり，前述したように，図-1 (d) の透礫層の存在 は植物の繁茂を抑制し ${ }^{3)}$, 河原らしい裸地の環境を維持 する上で重要である.（a）表層細粒土層は砂礫層の表面 に砂やシルトのみからなる土砂層が形成された状態を表 し，いわゆる樹林化した箇所は砂やシルトが堆積しやす く，このような状態となっていることが多い. (b) マト リクスは砂磒層の表面を砂やシルトが覆うまでには至つ ていないが，表層の礫の間に砂やシルトが確認される状 況を表す。一般的には砂やシルトなど礫間の充填物をマ トリクスと呼ぶが，ここではこの状態をマトリクスと分 類した. なお，この状態は一年生草本類の繁茂する河原 によく見られる.（d)透碟層については 2 章で詳しく述 べるが，河床表面が数個の重なり合った砶層によって構 成されているのに対して，(c)マトリクス’ は礫層を一 層剥がすと砂やシルトが確認できる点で透碩層と異なる. また，マトリクス’は一年生草本類が繁茂する河原でよ く見られ，透礫層ではなくマトリクスに近い状態である ことに注意したい，榎本ら ${ }^{4}$ は，平水位からの比高と河 床表層の状態によって，そこに繁茂する植物を数タイプ に分類している. また, 表層細粒土層の形成に伴って, 植物の繁茂が促進され樹林化へと至ることは李ら ${ }^{2)}$ よって述べられてきたとおりである.このように河床表 層の状態はそこに成立する植物群落, ひいては生物群集 を規定する上で重要な役割を果たす。 


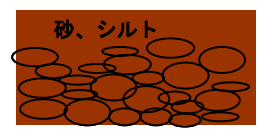

(a) 表層細粒土層

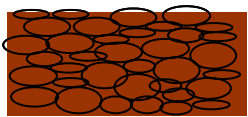

(b) 一般礫層 (怆クス)

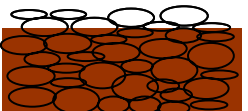

(c)一般碟層 (マ訬クス’ )

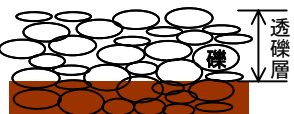

(d) 透鿬層

図-1 河床表層 の状態の分類

そこで，本研究では，摚乱後の河床表層の状態を予測 することを最終的な目標として，透碩層の形成環境と形 成後の充填過程に注目寸る，以下では，透碩層に関する 既往の研究に触れた後, 現地で観測された透砂層の形成 環境とその後の変化，特に透碩層の充填過程について述 べる.ここで，充填とは透碩層内へ砂やシルトが沈降し， マトリクスの状態へと変化していく状況を表すものであ り, 充填の進行する速さを充填速度と表現する. また, 室内水路実験によって透碩層の充填過程を再現し，その 充填速度を計測するとともに，その予測式を提案した.

\section{2. 透磁層の形成環境}

礫層は一般に碩間が砂やシルトによって充填された状 態であるが，空隙に充填物が存在せずに㗂のみによって 構成される礫層も存在する。ここでは，池田 ${ }^{5}$ にならつ て，前者を一般硯層（図-1 (b)，（c)），後者を透礫層 (図-1 (d) ) と呼ぶ。池田 ${ }^{5}$ は，一様粒径に近い砂礫を河 床材料として用い，砂と㗂の混合特性および水理条件を 変化させ，水路実験によって透碩層の形成要因を調べた。 その結果, Smith ${ }^{6}$ が提案した, 強い水流による㗜間の砂 の巻き上げは透碩層の形成要因にはならず，以下の二つ のパターンで透礫層が形成されることを明らかにした。 (1)交互砂州等の中規模河床波の形成に伴って，砂䃇堆上 流側では一般砅層，下流側では透㗂層が形成される。 こ の場合，河床材料中の含砂率が大きい場合には，その形 成領域は小さくなる. (2)dune等の小規模河床波の形成に 伴って, 礫の堆積環境となる河床波頂部で透碩層が形成 される，この場合，含砂率が大きくなると，透碩層は形 成されない，ここで，含砂率とは河床付近に存在する河 床材料中に含まれる砂の割合を述べており，掃流砂，浮 遊砂および河床の砂碩を合わせて河床材料として見た時 の，河床材料中に含まれる砂の割合を表す，以下では，
前者を中規模河床波型透碩層，後者を小規模河床波型透 碩層と呼ぶが，両者とも砂礫の堆積環境で形成されるこ とは共通している．また，形成された後の土砂の充填機 構は共通しているものと考えられる.

\section{3. 北川における透碟層の形成とその後の変化}

本節では，五ヶ瀬川支川北川の河口から約 $9 \sim 12 \mathrm{k} \mathrm{m}$ に位置する的野地区および本村地区（平均河床勾配 $\mathrm{I}_{\mathrm{b}}=1 / 1,000$ ，代表粒径 $\mathrm{d}_{\mathrm{R}}=25 \mathrm{~mm}$ ，セグメント $2-1$ ，図-2参 照）を対象として，最近の洪水によって形成された透砅 層とその後の充填過程を調査した結果を示す．図-3(a), (b) は, 図-2 (a)の矢印の方向に撮影したパノラマ写真で ある．上流側の右岸にある砂州に注目寸ると，同時季に 撮影した写真であるにもかかわらず，植物群落の面積が 2 年前に比べ拡大していることを確認できる. 図-3(c)， (d) は, LA測線下流で河床に $30 \mathrm{~cm}$ 程度の深さのトレンチ を掘り，河床表層の状態を調査した結果である． 2 年前 までは厚さ $10 \mathrm{~cm}$ 以上の透碟層が存在していたのに対して, 近年では表層まで土砂が充填され，マトリクスの状態に 変化していることを確認できる。 これまでの調査結果か ら，この変化は2002年以降徐々に進行し，2004年夏には 砂州上の透㗂層がほとんどマトリクス状態に変化してい たことを確認している.

図-4は，観測水位のピーク值(指定水位以上)を示寸. また，図中には当該区間の砂州が冠水する概略の水位を 示した.1997年9月の出水は河川激甚災害特別事業(以下， 激特事業)に採択されるきっかけとなった出水であり， その後 5 年を経て 2003 年 3 月頃には激特事業(高水敷の掘 削，樹木の伐採等)がほぼ完了している. 的野地区の上 流に位置する本村地区における調査結果から， $1,600 \mathrm{~m}^{3} / \mathrm{s}$ 以上の流量が 2 年半程度発生しない場合に, 裸地であった砂州上に草本が全面を覆うように繁茂する ことが調べられている7)。これは䃇を移動させるような 洪水による河床の擋乱頻度に着目したものであるが, 

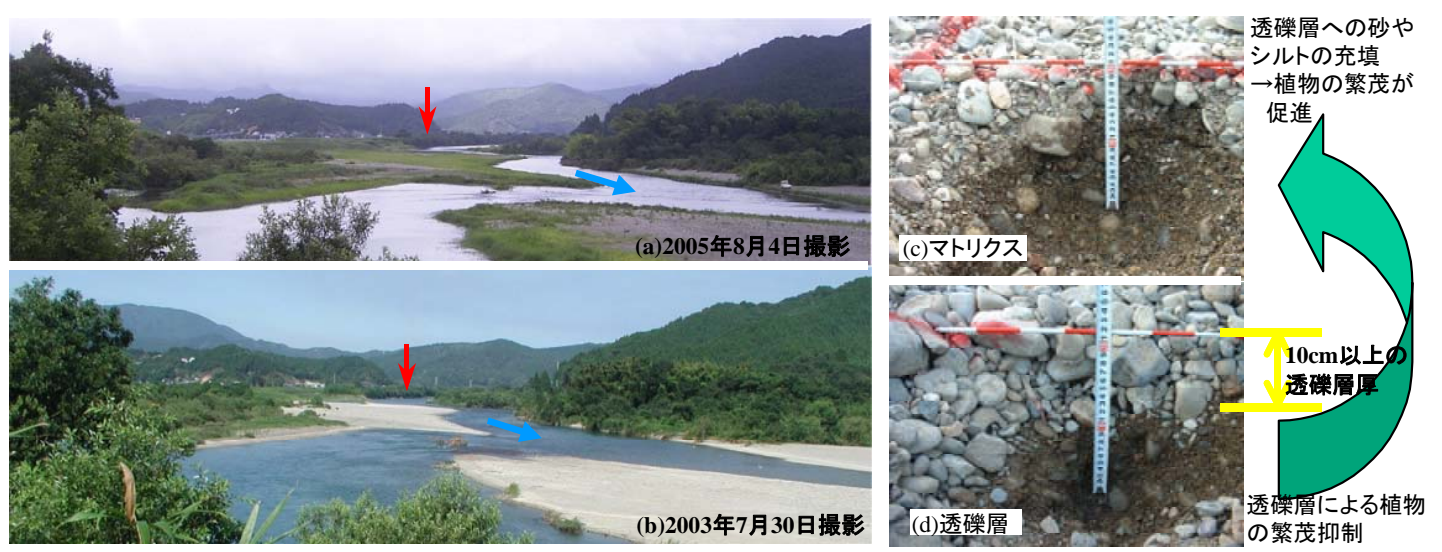

図-3 砂州上の植物の繁茂状況とその立地基盤として重要な河床表層の状態の変化

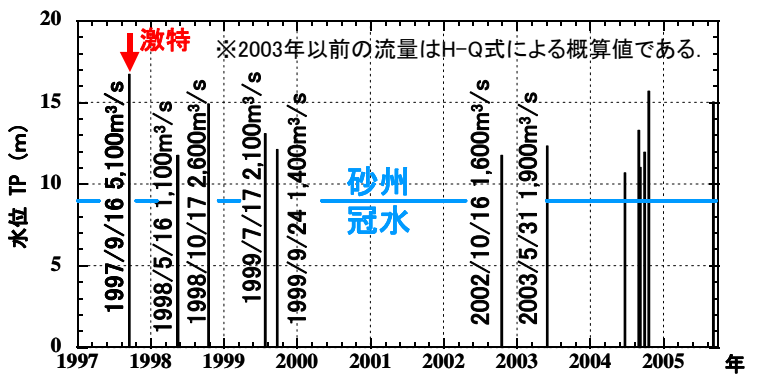

図-4 1997年以降の出水状況（熊田水位観測所）

図-3に示した砂州上では出水状況にかかわ水らず裸地が広 がっていたことを1999年から2002年にかけて作成された 植生図によって確認している ${ }^{8)}$ 。また, 図-5は図-2(b) の矢印の方向に撮影した写真であり，2003年5月の出水 によって形成された砂州であるが，砂州上の半分程度が 透礫層となっており，その部分には植物がほとんど繁茂 していなかった，すなわち，透碩層の存在は植物の繁茂 を抑制し，砂州上に河原らしい環境を形成する上で重要 であったと言える.

激特事業が完了した 2003 年3月以降について見ると， 2003年5月の出水等により地形は大きく変化し，図-2の 丸で囲んだ部分に新たに透碩層が形成されたことを現地 踏査によって確認した. なお，この透礫層が形成された 箇所の地形変化の特徽は，池田の指摘したように砂礫が 堆積した箇所であった．2003年5月の出水は激特事業完 了後に生じた初めての指定水位以上の出水であり, 多量 の土砂が上流から供給され，当該地区に堆積したことが 出水後の横断測量結果によっても確認されている. また, これらは中規模河床波型透碩層と分類できるが，LF測線 では，図-6に見られるような波長 $17 \mathrm{~m} ，$ 波高 $0.5 \mathrm{~m}$ 程度の 河床波が観測され，小規模河床波型透碟層も一部で形成 されていた。これは，2004年10月に発生した出水(激特 事業のきっかけとなった1997年9月出水規模に相当)に よって形成されたものであり，的野内岸(LB測線)でも同 様な河床波の発生と透砂層の形成が確認されている．以 上述べてきたように，透碩層は掃流によって流送されて きた砂磕が堆積する環境で形成される地形であることが 現地でも確認された.

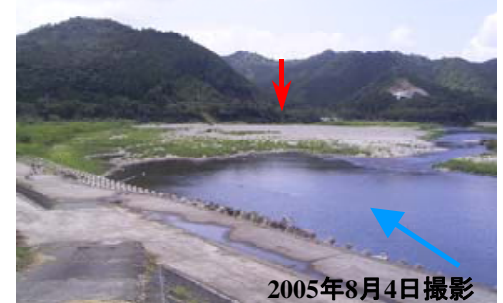

図-5＼cjkstart透碟層が形成された砂州上に広がる裸地

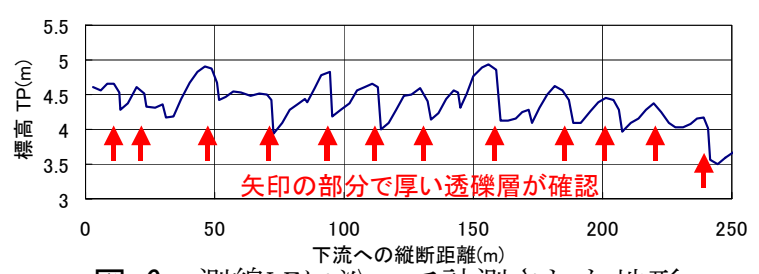

図-6 測線LFに沿つて計測された地形

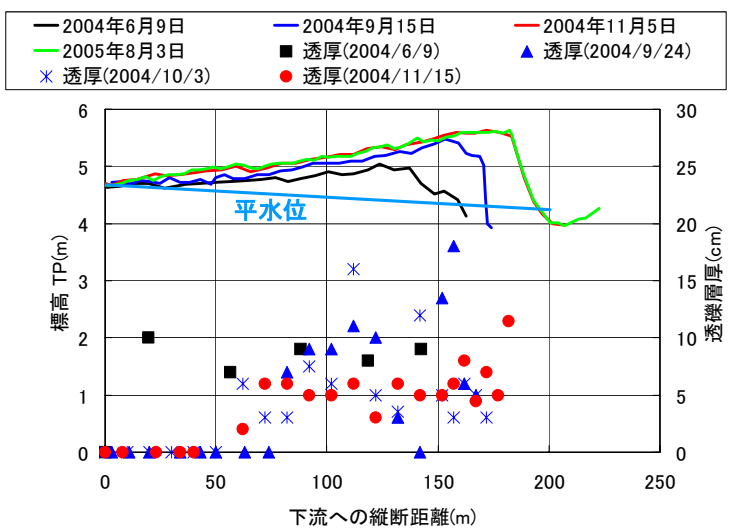

図-7ＬC測線上における標高と透碟層厚の変化

次に, 透碟層形成後の変化について観測結果を示寸. 図-7は，図-2 (b) の調査測線LC上で標高(約 $2 \mathrm{~m}$ 間隔で測 量)および河床表層の状態(約 $10 \mathrm{~m}$ 間隔で測定)を調査した 結果である.ここで, 透碩層厚さは図-3と同様にトレン チを掘り調査した結果であり, 透碟層厚ゼロの部分は一 般礫層の状態を表す．また，前縁線の下流は水裏部であ り, 前縁部の状況とは一変して細粒土砂が堆積し, 植物 の繁茂が著しい箇所となっていた。2004年6月時点にお いては，2003年5月出水によって砂州が形成されて以来, 


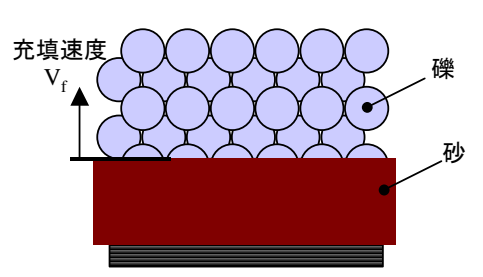

図-8＼cjkstart充填速度の定義

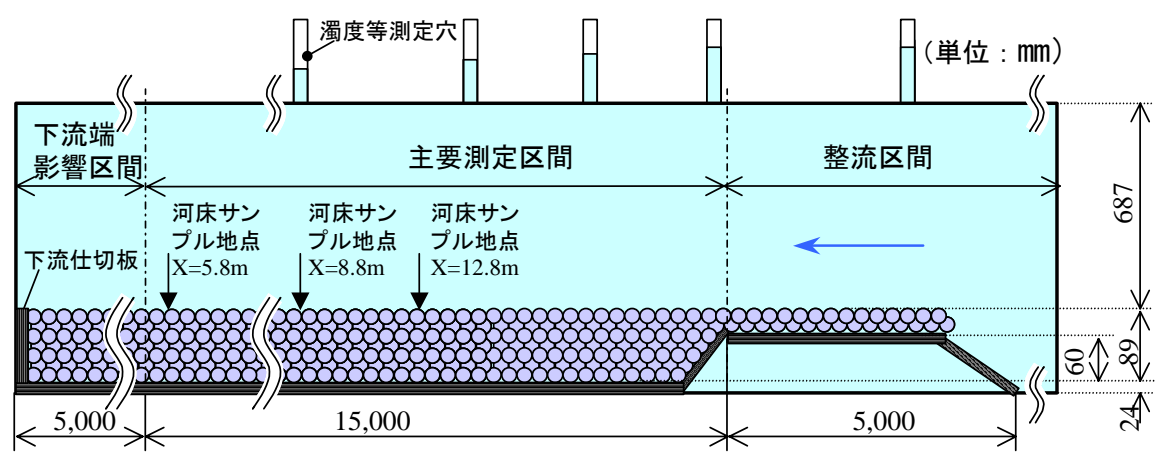

図-9 実験水路の概要 (全長 $25 \mathrm{~m}$, 幅 $1 \mathrm{~m}$ ，高さ0.8m)
砂州が冠水するような出水を受けておらず，砂州の形成 直後と同様な状態であり，10cm程度の厚さの透砂層が測 線全体で確認された，その後，2004年に発生した数回の 出水によって徐々に上流から土砂が充填されると同時に, その下流側の透碩層厚さも薄くなってきている. 一方, 砂碩堆前縁部では砂碩が堆積し, その部分には厚い透碩 層が形成されたことが確認された。 図 - 7の縦断距離50 〜140m区間においては，2004年8月に発生した出水等に よって河床が $20 \mathrm{~cm}$ 程度上昇したが，その部分の透硯層厚 さはほとんど変化していない。これは, 碩の堆積に伴っ て透磎層が一時的に形成された後, 洪水減衰期に再び充 填された可能性が高い，それを示唆するように，地形変 化の少ない縦断距離 0 ～50m区間の透㗜層は完全に充填さ れ，その厚さがゼロの一般碩層の状態へと変化していた。 ここで, 洪水中に河床が一時的に低下し，洪水前と同じ 河床高まで埋め戻される变化が生じていた可能性もある が，上と同様に一時的に透㗂層が形成され，その後充填 されることで, 図 - 7の結果が得られたものと類推され た. なお，LD，LE測線についても同様な傾向であった.

次章では, 浮遊砂による透碩層の充填過程を水路実験 によって再現した結果を報告するが，その前提条件とし て現地でも土砂が浮遊する条件であったことを，本村地 区上流で計測された横断測量結果とその地点の2003年5 月出水の水位記録から述べておく.それによると，洪水 中の摩擦速度は砂州冠水直後〜洪水ピーク時に掛けて 13. $8 \sim 21.4 \mathrm{~cm} / \mathrm{s}$ と変化し, 透碩層内に堆積した細粒土砂 (粒径 $1 \mathrm{~mm}$ 程度)の沈降速度が $9.8 \mathrm{~cm} / \mathrm{s}$ 程度であること, ま た，充填された土砂に $1 \mathrm{~mm}$ 以下の粒径も多く含まれてい たことから，冠水直後は完全な浮遊状態ではないが，洪 水ピーク時には浮遊する条件であったことを確認できる.

\section{4. 透礫層への土砂充填実験}

透砅層は砂磁が堆積する箇所に形成され，上流から浮 遊してきた細粒土砂が間隙に堆積することで上流から 徐々に一般硆層へと変化していくことが前章までに確認 された．ここでは，透砂層が一般砂層へと変化する過程
表-1 実験条件

\begin{tabular}{|c|l|l|r|r|}
\hline ケース & 河床材料 & 給砂材料 & $\begin{array}{c}\text { 流速 } \\
(\mathrm{m} / \mathrm{s})\end{array}$ & $\begin{array}{c}\text { 設定濃度 } \\
(\mathrm{mg} / \mathrm{l})\end{array}$ \\
\hline 1 & 礫+粗砂 & 細砂 & 1.0 & 300 \\
\hline 2 & 磁 & 細砂 & 1.0 & 100 \\
\hline 3 & 磁 & 細砂 & 1.0 & 300 \\
\hline 4 & ビー玉 & 細砂 & 1.0 & 300 \\
\hline
\end{tabular}

を水路実験によって再現し，その充填速度を調べるもの とする. なお，充填速度とは前述したように透碟層中に 細粒土砂が堆積する時の堆積面の上昇速度である (図-8 参照)。また, 河床を構成する礫の移動の有無, 縦断的 な冠水頻度の有無の 2 点において, 実験は現地と異なる が，ここでは充填速度の概略值を把握することが目的で あり, 充填過程については現地と同様の現象と考える.

実験では図-9に示寸閉水路を用い，整流区間から約 $5 \mathrm{~m}$ 上流の水路天井に接続された土砂供給口から一定量の給 砂量になるように細砂を供給しながら, 表-1の実験条件 のもと充填速度を測定した. ここで，表中の流速は断面 内平均流速であり，上流端流量を変えることで調整した。 河床材料の粒径としては碩 $17.5 \mathrm{~mm}$, ビー玉 $15 \mathrm{~mm}$, 粗砂 $2 \mathrm{~mm}$ ，細砂 $0.25 \mathrm{~mm}$ 用いた．測定にあたっては，側壁の 影響を除去するため, 水路中央部における充填速度を測 定した. 通水途中に適当な時間間隔で上流側から砂鉄を 流下させ，ある時間間隔で黒い砂鉄の層を薄茶色の砂層 の間に挟む. 通水後にドライアイスによって水路中央部 の河床 $(50 \mathrm{~cm} \times 50 \mathrm{~cm}$, 厚さ $9 \mathrm{~cm}$ 程度)を凍結させ, 周辺の 河床材料を取り除き, 層構造を露出させ, 細粒土砂の充 填速度を算出した. ケース 1 は、細砂が堆積する前に粗 砂が堆積する場合を想定したものであるが，道上ら岗が 指摘したように，粒径が 1 オーダー以上小さい材料でな い場合には礫の下層まで充填されず，その後細砂が給砂 されても粗砂表面に留まり礫の下層までは沈み込むこと はなかった。

図-10は, ケース 3 およ゙ 4 にいて, 露出された層 構造を示寸．上流側の砂鉄層の間隔が下流側のそれに比 べて広く, 上流側の充填速度の方が下流に比べて速いこ とが分かる．現地では河床を構成する骨格部分である礫 層が擋乱を受けることなどもあり，必ずしも実験と同じ 条件ではないが，透砂層が上流から徐々に充填されてい 


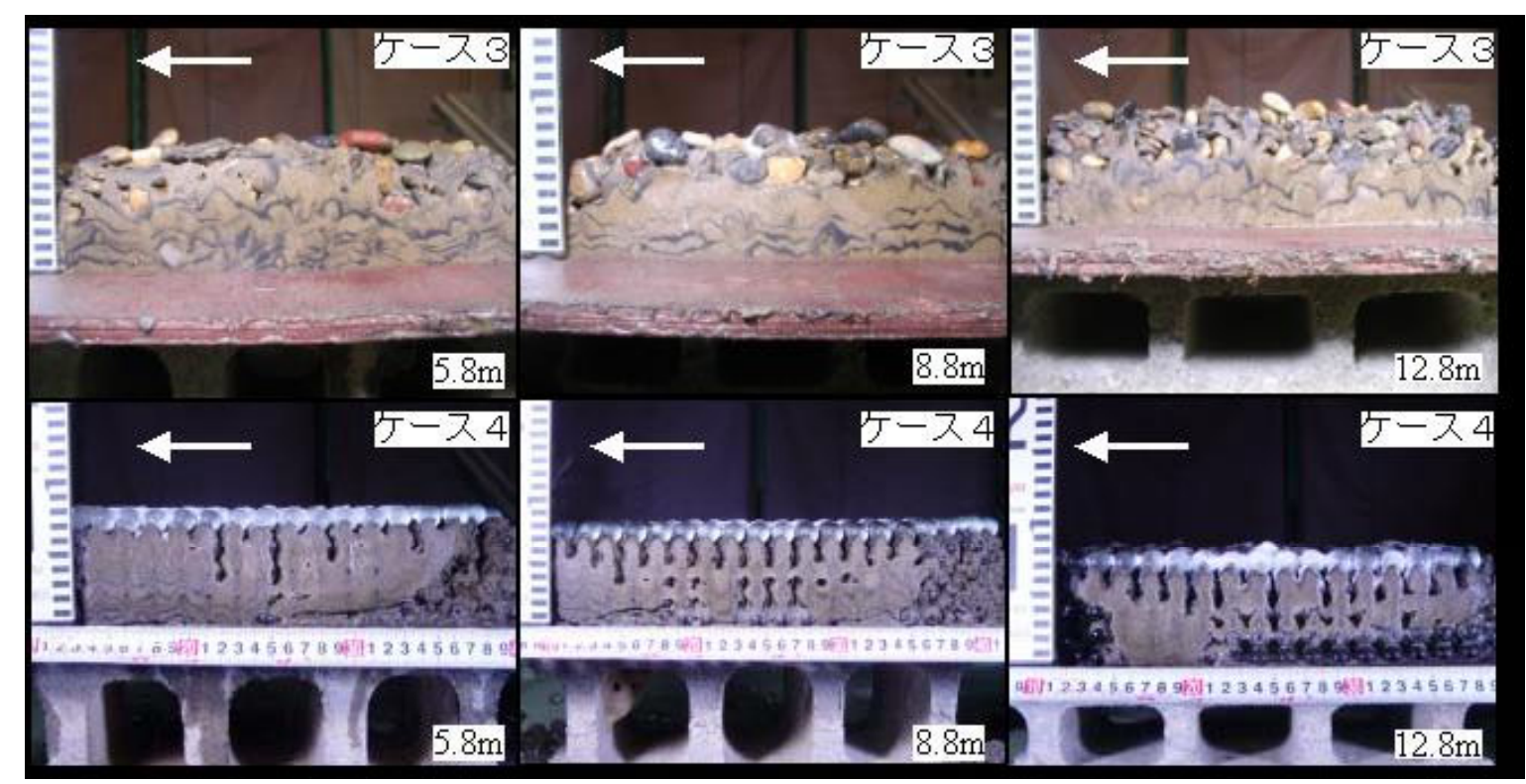

図-10 透礫層内への土砂の充填状況（露出した縦断面, 黒色の層は砂鉄）

表-2 透碩層への土砂の充填速度

く状況は現地と類似していた．実験中の観察結果による と，浮遊砂のうち河床の間隙に落下した土砂は再び巻き 上がることがなく，縦断方向に土砂濃度の鉛直分布を計 測した結果からも，下流に向かって濃度が低下している 状況を確認できた．また，ビ一玉を使った実験は現象を 見やすく寸るために行ったが，通水後水槽から水を抜く 際に水みちが形成され, 砂鉄の層構造が崩れたため, 自 然の碩に比べ層構造が見えにくくなった. なお，充填速 度については自然の㗂を用いたケースと同程度であった。 表-2には，図-10の層構造から算出した充填速度を示す. ケース 2 については砂鉄層を確認できた縦断距離 $5.8 \mathrm{~m} の$ みの結果を示した。

\section{5. 充填速度の予測式の提案}

透碩層内一の土砂の充填速度を予測する上で, 李らの 研究 ${ }^{2)}$ が参考になる. 李らは, 高水敷上に繁茂する植生 群落内一浮遊砂を含んだ水塊が進入した時の, 細粒土砂

（粒径0. 1 0. $\mathrm{mm}$ ）の堆積過程を以下のモデルを使って 予測し, 流下方向に向かって徐々に堆積厚が薄くなる状 況を再現した. 前章の実験においても, 透碴層が上流側 から充填され，下流に向かって充填速度が遅くなる点が 類似している.

透碩層内一の細粒土砂の充填速度を $V_{f}$ とすると，

$$
\left.\begin{array}{ll}
V_{f}=\left(C_{b}-C_{a}\right) w_{0} /(1-\lambda) & C_{a}<C_{b} \text { の時 } \\
V_{f}=0 & C_{a} \geq C_{b} \text { の時 }
\end{array}\right\}
$$

のように表現できる，ここで， $C_{b}$ は底面濃度， $C_{a}$ は基準 面濃度， $w_{d}$ は対象と寸る細粒土砂の沈降速度，入は細粒 土砂の空隙率であり， $C_{b}$ は鈆直平均濃度を $C$ とした時, (2)〜 (4)式によって表現される.

\begin{tabular}{|c|r|r|r|r|r|}
\hline ケース & $\begin{array}{c}\text { 縦断距離 } \\
(\mathrm{m})\end{array}$ & $\begin{array}{c}\text { 実験値 } \\
(\mathrm{mm} / \mathrm{min})\end{array}$ & $\begin{array}{c}\text { 底面濃度 } \\
(\%)\end{array}$ & $\begin{array}{c}\text { 予測值 } \\
(\mathrm{mm} / \mathrm{min})\end{array}$ & $\begin{array}{c}\text { 予測值 } \\
\text { 実験値 }\end{array}$ \\
\hline Case2 & 5.8 & 0.3 & 0.004 & 0.4 & 1.5 \\
\hline \multirow{3}{*}{ Case3 } & 5.8 & 0.7 & 0.011 & 1.1 & 1.7 \\
\cline { 2 - 6 } & 8.8 & 0.8 & 0.024 & 2.3 & 3.0 \\
\cline { 2 - 6 } & 12.8 & 1.8 & 0.033 & 3.2 & 1.8 \\
\hline \multirow{3}{*}{ Case4 } & 5.8 & 0.6 & 0.011 & 1.1 & 1.8 \\
\cline { 2 - 6 } & 8.8 & 1.0 & 0.024 & 2.3 & 2.3 \\
\cline { 2 - 6 } & 12.8 & 1.6 & 0.033 & 3.2 & 2.0 \\
\hline
\end{tabular}

$$
C_{b}=\eta C
$$$$
\eta=6 Z /\{1-\exp (-6 Z)\}
$$

$$
Z=w_{0} /\left(\beta \kappa u_{*}\right)
$$

ここで， $\beta$ は鉛直混合に関する拡散係数と渦動粘性係数 の比（=1.2），ヶはカルマン定数（=0.4）である. 式 （1）は，基準面濃度以上の浮遊砂が流入した場合，すな わち細粒土砂の沈降量が巻き上げ量に比べ大きくなった 場合に河床に堆積するモデルとなっている.

透砅層内一の土砂充填実験においては，透碟層が表面 近傍まで充填されていない段階においては, 河床からの 巻き上げが確認されていない，すなわち，李ら ${ }^{2)}$ が植生 群落内で仮定したように， $C_{a} \fallingdotseq 0$ と仮定してよいものと 考えられる. さらに, 透礫層内一の堆積, 寸なわち硆間 のみへの堆積であることを考えると, 充填速度として,

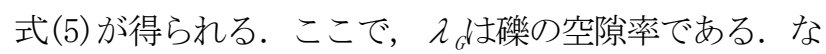
お, 実験時の測定結果によると, 砂の空隙率は0.34であ り，ビー玉を配置した際にもこの空隙率に近くなるよう に体心立法格子として配置した.

$V_{f}=C_{b} w_{0} /(1-\lambda) / \lambda_{G}$

式(5)を使って充填速度を算出するためには, 底面濃 度と沈降速度を求める必要がある. 沈降速度はRubeyの 


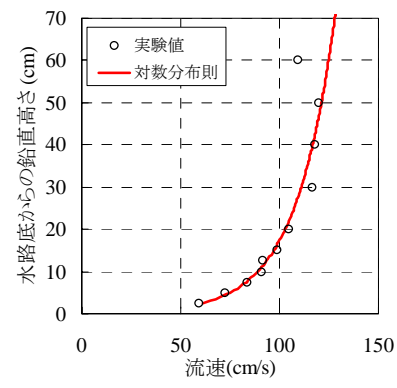

図-11 流速の鉛直分布

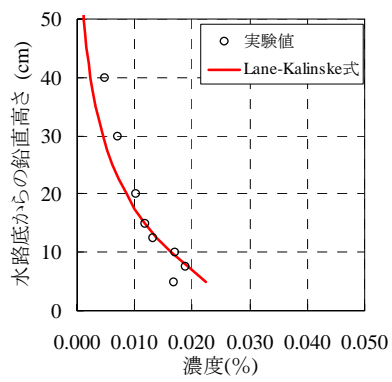

図-12 浮遊砂濃度の鉛直 分布

式から $3.3 \mathrm{~cm} / \mathrm{s}$ と算定した。底面濃度は，摩擦速度と鉛 直平均濃度を与えると, 式(2)～(4) 加充填速度を算定 できる，前章で示した実験では，層構造を露出した近傍 で流下方向流速および浮遊砂濃度の鉛直分布をそれぞれ レーザー流速計および濁度計によって計測している.

図-11は，下流から8.4m地点で測定された流速分布を対 数分布則と比較した結果であるが，境界層が十分に発達 し，対数分布則との適合性がよいことが分かる．相当粗 度として, 河床材料の 2 倍の粒径を与え, 流速の計測值 にフィットするように摩擦速度を算出すると $8 \mathrm{~cm} / \mathrm{s}$ と なった。 また, 図-12は浮遊砂濃度の鉛直分布をLaneKalinske式と比較した結果である.これらの結果から充 填速度を算定し，その結果を表-2に示した.

表-2の結果は，多少過大評価であるが，洪水中に形成 された透㗂層がごの程度の時間で土砂によって充填され るかを概算するのに有効である。例えば，エネルギー勾 配が $1 / 400$, 水深が $2 \mathrm{~m}$, 減衰時に鉛直平均濃度が $300 \mathrm{mg} / 1$ の状態が 1 時間継続したと仮定すると, 洪水中に形成さ れた透碩層のうち $13 \mathrm{~cm}$ 程度が砂で充填され, 徐々にマト リクス状態へと変化することを予測できる，なお，河床 材料の空隙率を $40 \%$ ，細粒土砂の粒径を $0.25 \mathrm{~mm}$ として評 価した結果であり，上記の仮定が通常の河川でも生じう る一般的な仮定であることから，䃯層の移動に伴って形 成された $10 \mathrm{~cm}$ 程度の透䃋層は 1 回の洪水で容易に充填さ れることが理解された。

\section{6. おわりに}

本論文で得られた結果を整理すると以下の通りである. (1)透碩層の存在は植物の繁茂を抑制し，裸地である環境 の維持に有効である。(2)透碩層は砂碟が堆積寸る環境に 形成されや寸く, 再び河床が摚乱を受けない限り, 徐々 に土砂によって充填され，上流側から一般碩層へと変化 していく. 室内実験では上下流の浮遊砂濃度の違いから 上流側の充填速度が速かったが，現地ではさらに冠水頻 度や擋乱の影響も考慮する必要がある。（30透礫層の充填 速度を浮遊砂の鉛直平均濃度と沈降速度によって予測す ることができた.
本結果から洪水中に形成された透砶層はかなりの速度 で洪水減衰期に充填されることが示され，洪水後には透 碩層が形成されにくい状況が予測されたが，その形成の 仕組みには，流量と浮遊砂濃度のピークのずれが影響す ると考えられた．具体的には，洪水ピーク前に浮遊砂濃 度のピーク值が現れ, 減衰期には浮遊砂濃度が相当低下 しているような河川では透碩層が形成されやすいと考え ている.ちなみに，北川的野地区では自記式濁度計によ り洪水時の浮遊砂特性を調べているが, 洪水ピーク前に 浮遊砂濃度のピークが現れ, 洪水減衰期には浮遊砂濃度 がかなり減少していることを確認している，今後は，八 イドログラフと浮遊砂濃度の関係に焦点を当て, 透礫層 の形成されやすい環境について検討する予定である.

謝辞 : 本研究は北川における河川生態学術研究会の総合 的な調查研究の一環として実施されたものである. 宮崎 県延岡土木事務所，国土交通省延岡河川国道事務所には 調査にあたって多大な協力を得た．また，河川研究室の 元交流研究員である佐藤孝治氏 (現 中電技術コンサルタ ント(株))および榎本真二氏(現（株）ウエスコ)には現地 調查等で協力いただいた。 ここに記して謝意を表する.

\section{参考文献}

1) 服部敦·瀬崎智之·伊藤政彦・末次忠司: 河床変動の観点で捉元 た河原を支える仕組みの復元，河川技術論文集，第9巻， pp. 85-90, 2003.

2) 李参熙 $\cdot$ 山本晃一 - 望月達也 $\cdot$ 藤田光一 ・ 塚原隆夫 $\cdot$ 渡辺 敏: 扇状地砂床河道における安定植生域の形成機構に関する 研究，土木研究所資料，第3266号，pp.51-111，1999.

3) 渡辺敏・藤田光一・塚原隆夫 : 安定した砂磁州における草本 植生発達の有無を分ける要因, 水工学論文集, 第42巻, pp.439-444, 1998.

4) 榎本真二 ・服部敦 ・瀬倚智之 ・ 伊藤政彦・ 末次忠司 ・ 藤田光 一: 碩床河川に繁茂する植生の洪水摚乱に対する応答, 遷移 および群落拡大の特性, 河川技術論文集, 第10巻, pp.303308, 2004.

5) 池田宏 : 透㗂層の成因に関寸る水路実験，地形，第3巻，第1 号, pp.57-65, 1982.

6) Smith, N. D. : Sedimentology and bar formation in the upper Kicking Horse River, a braided outwash stream, Journal of Geology., Vol.82, pp.205-223, 1974.

7) 杉尾哲・渡邊訓甫 : 北川における砂州の地形変化と植生域変 化㳊関する検討，水工学論文集，第48巻，pp.985-990， 2004.

8) 服部敦・福島雅紀・瀬㥓智之・伊藤政彦・末次忠司 : 砂砂の 移動と植生との関係, 北川の総合研究一激特事業対象区間を 中心として一, pp.2-2-1〜2-2-16, 2004.

9) 道上正規・藤田正治・北川豊広・三村光太郎 : 空隙の大きな 河床一の浮遊砂の沈み込み過程と非平衡浮遊砂, 水工学論文 集, 第38巻, pp.609-614, 1994.

(2005. 9. 30受付) 